\title{
LARGE SCALE PROPAGATION OF FRAGARIA ANANASSA PLANTLETS THROUGH SHAKE CULTURE; THE EFFECT OF CYTOKININ AND ABSCISIC ACID(ABA) ON SHOOT GROWTH
}

\author{
液体振とう培養によるイチゴ (Fragaria ananassa) の大量增殖に関する研究 \\ ーシュートの成育におよぼすサイトカイニンとA B A の影㲎一 \\ Naoko Tsumaki and Shinsaku Takayama \\ School of High Technology for Human Welfare \\ Department of Biological Science and Technolgy, Tokai University \\ 317 Nishino, Numazu, Shizuoka 410-03, Japan \\ TEL:0559-68-1111(Ext.2104) FAX:0559-68-1151 \\ (Received 26, November 1992 Accepted 11, March 1993)
}

\begin{abstract}
The effects of different cytokinin levels on multiplication of axillary shoots during culture on agar medium and subsequent growth of shoots in liquid shake culture were examined. The number of axillary shoot buds was highest(about 100) in culture medium containing $1 \mathrm{mg} / 1$ of $4 \mathrm{PU}$ (one kind of cytokinin).

Tissue segments with multiple shoot buds thus obtained were further grown in liquid medium by shake culture. The growth of shoot buds into plantlets in shake culture was examined for liquid media containing 0 , 0.1 and $1 \mathrm{mg} / \mathrm{l} 4 \mathrm{PU}$ in combination with $0,0.1,0.3$ and $1 \mathrm{mg} / \mathrm{l} \mathrm{ABA}$. The growth was most faborable in the medium containing $1.0 \mathrm{mg} / \mathrm{l} 4 \mathrm{PU}$ in combination with $0.1 \mathrm{mg} / \mathrm{l} \mathrm{ABA}$. Individual shoots grown under this condition were easily separated by hands, transplanted, and established satisfactorily in soil.
\end{abstract}

KEY WORDS:Fragaria ananassa, strawberry, tissue culture, propagation.

\section{1.はじめに}

イチゴはランナーによる栄養繁殖が主体である ため、ウイルスの感染による品質の低下が問題に なってきた。これに対する対策として、植物組織 培養によりイチゴのウイルスフリー株を繁殖させ、 土壌に移植して苗として供給するシステムが

B ox u sら(Ref.1)、D a m i a n o (Ref.2) によって報告され、組織培養によるイチゴの繁殖 が容易になった。しかし、これらはいずれも寒天 培地上での繁殖であるため、増殖勃率が決して高 くない。植物組織培養によって增殖したイチゴの ウイルスフリー個体を、娄場での栽培に直接利用 できるようにするためには、イチゴの苗を省力化 したプロセスで大量增殖することが必要である。 そのための手段として、著者らによって液体振と う培養による大量増殖が検討されている。その結
果によると、培養容器内で增殖した植物体の成育 が必ずしも良好ではなく、種苗を効率良く生産す るためにはさらに改良が必要である。そこで、本 研究では特に液体振とう培養による植物体の成育 促進による種苗の生産効率を高めることを目的に、 サイトカイニンとA B A の添加勃果について検討 し、所期の成果を得たので、その結果を以下に報 告する。

\section{2. 材料および方法}

宝交早生を常法によって菱頂培養し、無菌培養 株を作成した。本株をMS 改変培地（MS成分の うの $\mathrm{NH}_{4} \mathrm{NO}_{3} 、 \mathrm{KNO}_{3}$ 、

$\mathrm{C} \mathrm{a} \mathrm{C} 1_{2} ・ 2 \mathrm{H}_{2} \mathrm{O}$ ⿸ $1 / 2$ に減量した培地に ショ糖 $30 \mathrm{~g} / \ell$ 、添加したもの）に継代增殖し、 実験に供した。実験はMS 改変培地を基本とし、 
寒天培養を $24 \times 125 \mathrm{~mm}$ の試験管、液体培養を $300 \mathrm{ml}$ 容三角フラスコで行った。培養条件は $25{ }^{\circ} \mathrm{C} 、 2500$ ルクス連続照明とした。

\section{3. 結果および考察}

3. 1 サイトカイニンによる芽の分化促進 サイトカイニンとしてカイネチン（和光純薬製、 Lot №. ALL7879）、6-ベンジルアデニン（和光 純薬、Lot №. ECE2561 : 以下BA）、4-ピリ ジルフェニル尿素（協和醱酵 : 以下 $4 \mathrm{PU}$ ）をそ れぞれ $0 、 1 、 3 、 10 \mathrm{mg} / \ell$ の濃度で添加し、 芽の增殖に対する影響を寒天培地上で調べた。そ の結果、芽の増殖効率は $4 \mathrm{PU}$ U $1 \mathrm{mg} / \ell$ 添加し た時に最も良く、約 100 本の芽が形成された。

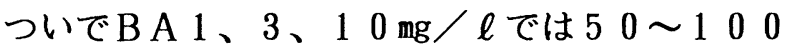
本の芽が形成された（Fig. 1A）。形成された芽の 伸長は、カイネチン添加区ではいずれの濃度でも 抑制されなかったが、4 PU、B A 添加区では

$1 \mathrm{mg} / \ell$ で顕著な抑制がみられた（Fig. 1B）。芽 の重量は $4 \mathrm{PU} 1 \mathrm{mg} / \ell 、 \mathrm{~B} \mathrm{~A} 3 \mathrm{mg} / \ell$ 、カイネ チン $10 \mathrm{mg} / \ell$ で促進され、4 P U $10 \mathrm{mg} / \ell$ で
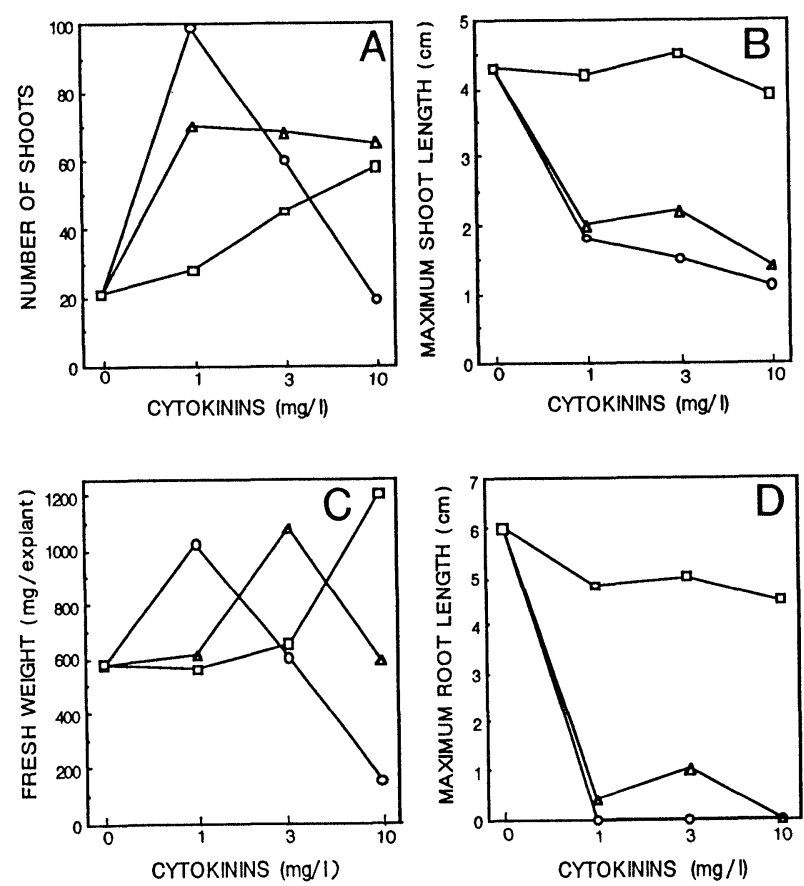

Fig.1.Effect of cytokinins on differentiation and growth in Fragaria ananassa in tissue culture. Symbols: $\bigcirc=4 \mathrm{PU} \quad \triangle=\mathrm{BA} \quad \square=$ kinetin
抑制された他は、無添加とほとんど変らなかった （Fig. 1C）。根の成長は、カイネチン添加区では ほとんぞ抑制されなかったが、4 P U、B A添加 区では顕著に㧕制された(Fig. 1D)。

以上の結果より、寒天培地上では $4 \mathrm{PU}$ $1 \mathrm{mg} / \ell$ 添加して培養することにより、芽の分化 数、培養株当たりのシュート重を增加させること ができた。

3 ・ 2 液体振とう培養における 4 P UとA B Aのシュートの成育に対する影響

芽の分化・成育はサイトカイニンを添加すると 促進されるが、植物体の水分含量が增加し、土壌 への活着率が低下する傾向がある（高山ら、未発 表）。この問題点を解決するために、成育促進勃 果を有するサイトカイニンとともに、植物体の八 ードニングを促進する傾向を有するアブシジン酸 (S I GMA、Lot №.41F-3810 : 以下A B A) を組み合わせて添加して成育ならびに土壤への活 着について検討した。

培養は $300 \mathrm{~m} \ell$ 容三角フラスコにMS 改変培地 $\left(\mathrm{MS}\right.$ 成分のうちの $\mathrm{NH}_{4} \mathrm{NO}_{3} 、 \mathrm{KNO}_{3}$ 、 $\mathrm{CaC} 1_{2} \cdot 2 \mathrm{H}_{2} \mathrm{O}$ ⿸ $1 / 2$ に減量し、 $\mathrm{Mg} \mathrm{SO}_{4} \cdot 7 \mathrm{H}_{2} \mathrm{O} 、 \mathrm{KH}_{2} \mathrm{PO}_{4}$ を 2 倍にし た培地にショ糖 $30 \mathrm{~g} / \ell$ 、添加したもの）に $4 \mathrm{PU} 0$ U $0.1 、 1.0 \mathrm{mg} / \ell 、 \mathrm{ABA} 0$ 、 $0.1 、 0.3 、 1.0 \mathrm{mg} / \ell$ の濃度でそれぞれ組み合 わせて添加した。測定は液体培地に移植して 20 日目に行った。その結果、フラスコ当たりの新鮮 重は $4 \mathrm{PU} 0.1 、 1.0 \mathrm{mg} / \ell$ 添加区ではA B Aを $0.1 \mathrm{mg} / \ell$ 組み合わせて添加することにより増加 した。特に 4 PU $1.0 \mathrm{mg} / \ell 、 A B A \quad 0.1 \mathrm{mg} / \ell$ 添加区ではその傾向が顕著でフラスコ当たり約 $30 \mathrm{~g}$ となり、他の試験区に比べ 2 倍〜 3 倍とな った。A B Aが $0.3 \mathrm{mg} / \ell$ 以上になると成育が顕 著に抑制された（Fig. 2A）。また乾物比率は、成 育が最も良好であった 4 P U $1.0 \mathrm{mg} / \ell 、 A B A$ $0.1 \mathrm{mg} / \ell$ 添加区のみで低くなった（Fig. 2B）。 シュートの数も $4 \mathrm{PU} 1.0 \mathrm{mg} / \ell 、 \mathrm{ABA}$

$0.1 \mathrm{mg} / \ell$ 添加区で最も多く、約 140 本得られ 

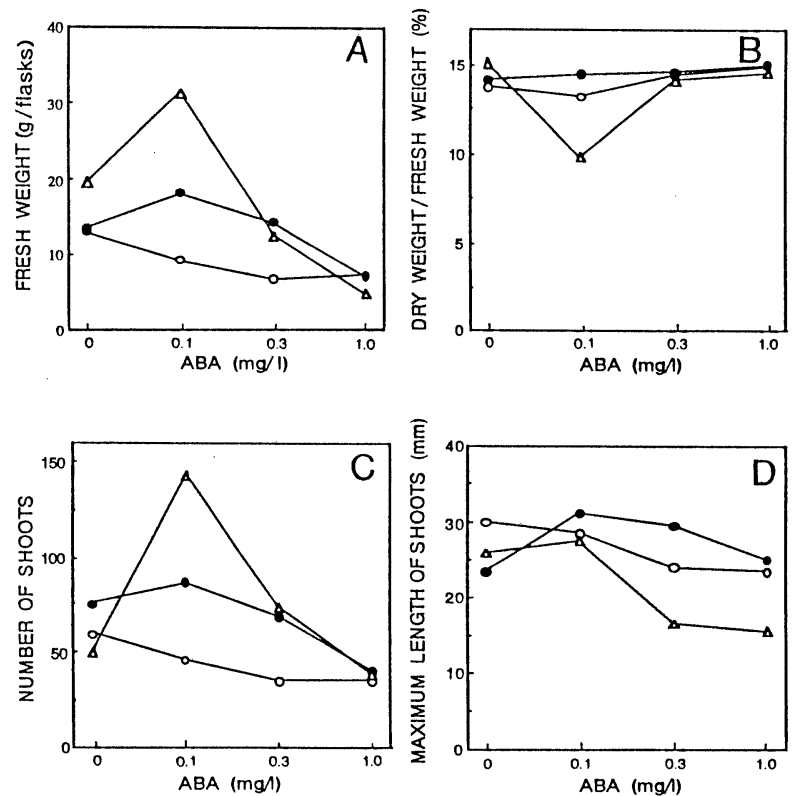

Fig.2.Effect of 4PU and ABA on differentiation and growth in Fragaria ananassa in tissue culture. 4PUconcentration:

$\bigcirc=0 \mathrm{mg} / \mathrm{l}, \bigcirc=0.1 \mathrm{mg} / 1, \triangle=1.0 \mathrm{mg} / 1$

た（Fig.2C）。シュートの高さは、4 P Uが0、

$0.1 \mathrm{mg} / \ell$ の時はA B Aの影響があまり見られな

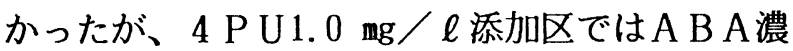
度が $0.3 \mathrm{mg} / \ell$ 以上になると抑制される傾向があ った（Fig. 2D）。発根は、ホルモンフリーの時と、 $\mathrm{ABA}$ 月みを $0.1 \mathrm{mg} / \ell$ 添加した時には観察され るが、ホルモンフリーの区と比べるとA B A

$0.1 \mathrm{mg} / \ell$ 添加区でも発根数が诚少し、根の伸長 が抑制された。それ以外の試験区ではほとんど発 根が見られなかった。

また、形成された植物体の特性を明らかにする ために、クロロフィル含量を測定した。その結果、 植物ホルモンを添加するとクロロフィル $\mathrm{a}+\mathrm{b}$ 含 量に変化がみられ、クロロフィル $\mathrm{a}+\mathrm{b}$ の含量は 4 P Uが高濃度になるにしたがって诚少した。 （Fig. 3A）。このクロロフィル含量の诚少が、土 壌への活着率の低下の原因のひとつであると考え られる。

以上の結果より、液体振とう培養によりシュー トを成育させる時には 4 P U $1.0 \mathrm{mg} / \ell$ とA B A $0.1 \mathrm{mg} / \ell$ を組み合わせて添加することにより成 育量、シュート数を增加させることができた。本
実験で増殖した植物体を土壤に移植し順化栽培を 行った結果、4 P U $1.0 \mathrm{mg} / \ell$ とA B A $0.1 \mathrm{mg} / \ell$ の組合せ添加によって成育したシュートの順化活 着は良好であった。

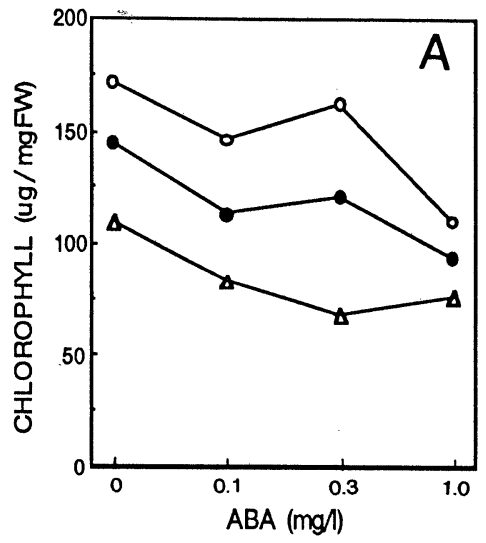

Fig.3.Effect of 4PU and ABA on chlorophyll content in Fragaria ananassa in tissue culture. 4PU concentration:

$\bigcirc=0 \mathrm{mg} / 1, \bigcirc=0.1 \mathrm{mg} / 1, \triangle=1.0 \mathrm{mg} / 1$

\section{4. おわりに}

液体振とう培養によりシュートを大量增殖して、 苗を農家に安定供給することは、イチゴの品質を 向上させるうえで重要である。今回の実験により、 液体振とう培養の材料となる寒天培地上での芽の 增殖は、MS 改変培地に $4 \mathrm{P} U$ を $1 \mathrm{mg} / \ell$ 添加す ることにより良好となった。また、液体振とう培 養でシュートを効率よく增殖するためには、 $4 \mathrm{P} \mathrm{U} 1.0 \mathrm{mg} / \ell 、 \mathrm{AB} \mathrm{A} 0.1 \mathrm{mg} / \ell$ を添加する と良いことがわかった。土培への活着率も、A B Aを添加した試験区で良好な結果が得られている。

\section{REFERENCES}

${ }^{1}$ Boxus, P. and Quoirin, M., Laine, J.M. : Large scale propagation of strawbery plants from tissue culture, In:Appliend and fandamental aspects of plant cell, tissue, and organ culture. :pp. 130-143 (1977)

${ }^{2}$ Damiano, C. and Laneri, U., Arias, E. J. : Nitrate and ammonium in strawberry micro propagagation preliminary results, Ann Ist Sper Fruttic 10:35-42(1979) 